\title{
PENGARUH KEADILAN ORGANISASIONAL TERHADAP KEPUASAN KERJA DAN KOMITMEN ORGANISASIONAL POLÍCIA NACIONAL DE TIMOR-LESTE (PNTL)
}

\author{
Lino Da Silva Saldanha ${ }^{1}$ \\ Wy. Gd. Supartha ${ }^{2}$ \\ Gede Riana ${ }^{3}$ \\ 1,2,3 Fakultas Ekonomi dan Bisnis Universitas Udayana, Bali, Indonesia \\ Email: linosaldanha@yahoo.com
}

\begin{abstract}
ABSTRAK
Istilah keadilan organisasi yang digunakan dalam penelitian ini adalah sejauh mana anggota organisasi merasakan tentang keseluruhan prosedur organisasi, aturan, dan kebijakan yang terhubung ke pekerjaan mereka. Tujuan penelitian ini adalah untuk menganalisis signifikansi hubungan antara tiga jenis keadilan organisasi (prosedural, distributif dan interaksional) terhadap kepuasan kerja dan komitmen organisasional. Penelitian ini dilakukan pada anggota Polícia Nacional De Timor-Leste (PNTL). Data dikumpulkan dengan kuesioner dari Chief Agent PNTL. Data yang telah dikumpulkan dianalisis menggunakan analisis deskriptif dan analisis jalur. Hasil penelitian menunjukkan bahwa persepsi anggota Chief Agent dalam PNTL menyatakan bahwa keadilan organisasional memiliki pengaruh positif signifikan terhadap kepuasan kerja. Penelitian ini juga menemukan bahwa kepuasan kerja anggota Chief Agent memiliki pengaruh positif signifikan terhadap komitmen organisasional di Polícia Nacional De Timor-Leste (PNTL).
\end{abstract}

Kata kunci : keadilan organisasional, kepuasan kerja, komitmen organisasioal.

\begin{abstract}
The term of organizational justice used in this study was the degree to which organization member perceived about the overall organizational procedures, rules, and policies which are connected to their job. The aim of this study was to explore the quality, strength, and significance of the relationship between three types of organizational justices (procedural, distributive and interactional) to job satisfaction and organizational commitment. The study would investigate the relationship between organization chief agent in the Polícia Nacional De Timor-Leste (PNTL). Data was collected through questionnaire and the data which had been collected and be analyzed using descriptive and path analysis. The results showed that the perception of chief agent member in the PNTL about organizational justice had a positive significan effect on their job satisfaction. This research also found that the job satisfaction of chief agent member had a positive significan effect on organizational commitment in the Polícia Nacional De Timor-Leste (PNTL).
\end{abstract}

Keywords: organizational justice, job satisfaction, organizational commitment. 
Lino Da Silva Saldanha, Wy. Gd. Supartha, Gd. Riana., Pengaruh Keadilan Organisasional........

\section{LATAR BELAKANG}

Keadilan organisasional mempunyai dampak pada sikap dan reaksi seseorang. Setiap orang menghendaki perlakuan yang adil baik dari sisi distribusi dan prosedur atau disebut sebagai keadilan distributif dan keadilan prosedural (Tjahjono, 2007). Keadilan distributif menunjuk pada sejumlah sumber penghasilan atau penghargaan pada para karyawan dan berhubungan dengan keadilan pengalokasian sumber penghasilan (Milkovich \& Newman, 2005; dalam Samad, 2006). Keadilan prosedural menunjuk pada proses yang digunakan untuk membuat keputusan pembayaran (Brockner dkk, 2000; dalam Samad, 2006). Keadilan prosedural memandang bahwa cara suatu keputusan pembayaran yang dibuat menjadi penting bagi para karyawan (Milkovich \& Newman, 2005; dalam Samad, 2006). Sedangkan keadilan interaksional sebagai persepsi individu tentang tingkat sampai dimana karyawan diperlakukan dengan penuh martabat, perhatian, dan rasa hormat (Robbins dan Judge, 2008).

Hasil penelitian dibidang organizational justice menunjukkan bahwa ketika para karyawan diperlakukan adil, mereka akan mempunyai sikap dan perilaku yang dibutuhkan untuk keberhasilan perubahan organisasi bahkan dalam kondisi sulit sekalipun (Sugiarti, 2005). Sebaliknya, ketika keputusan organisasi dan tindakan manajerial dianggap tidak adil maka karyawan akan merasa tidak puas dan menolak upaya-upaya perubahan untuk perbaikan organisasi. Hal ini akan menyebabkan 
beberapa karyawan kemungkinan mendapatkan hasil yang mereka harapkan sedangkan karyawan lain kemungkinan mendapat sebaliknya.

Menurut Thibaut \& Walker (1975) penilaian seseorang mengenai keadilan tidak hanya dipengaruhi oleh apa yang mereka terima sebagai akibat keputusan tertentu, tetapi juga pada proses bagaimana keputusan tersebut dibuat (Greenberg, 1990;; Sugiarti, 2005). Apabila mereka menilai bahwa perlakuan yang mereka terima adil maka akan berpengaruh pada kepuasan dan komitmen. Semakin tinggi mereka mempersepsikan keadilan suatu kebijakan ataupun praktek manajemen akan berdampak pada peningkatan kepuasan kerja dan komitmen organisasi.

Penelitian yang dilakukan Samad (2006) tentang pengaruh antara keadilan prosedural dan keadilan distributif terhadap komitmen organisasi dan kepuasan kerja. Hasil penelitian menyatakan bahwa keadilan prosedural dan keadilan distributif secara positif berhubungan dengan kepuasan kerja. Hasil lain yang diperoleh adalah keadilan distributif lebih berpengaruh baik pada kepuasan kerja maupun komitmen organisasi dari pada keadilan prosedural. Dalam hal ini, keadilan distributif lebih dominan mempengaruhi kepuasan individual seseorang dibandingkan dengan keadilan prosedural. Hal tersebut disebabkan setiap individual memiliki perhatian dan minat atas pendapatan bagi kesejahteraan mereka. Implikasinya, organisasi perlu mengkaji aspek alokasi tersebut terkait dengan perhatian dan minat setiap karyawan pada penilaian kinerja. 
Lino Da Silva Saldanha, Wy. Gd. Supartha, Gd. Riana., Pengaruh Keadilan Organisasional........

Cropanzano et al. (2007) menyatakan terdapat tiga alasan mengapa karyawan peduli terhadap masalah keadilan. Pertama, manfaat jangka panjang, karyawan lebih memilih keadilan yang konsisten daripada keputusan seseorang, karena dengan keadilan tersebut karyawan dapat memprediksi hasil di masa yang akan datang. Karyawan juga dapat menerima imbalan yang tidak menguntungkan sepanjang proses pembayarannya adil dan mendapat perlakuan yang bermartabat. Kedua, pertimbangan sosial, setiap orang mengharapkan diterima dan dihargai oleh pengusaha tidak dengan cara kasar dan tidak dieksploitasi. Ketiga, pertimbangan etis, orang percaya bahwa keadilan merupakan cara yang secara moral tepat dalam memperlakukan seseorang . Cropanzano et al. (2007) mendefinisikan keadilan organisasional sebagai penilaian personal mengenai standar etika dan moral dari perilaku manajerial. Dalam menilai keadilan organisasional setidaknya terdapat tiga bidang yang harus dievaluasi, yaitu :imbalan, proses, dan hubungan interpersonal (Cropanzano et al., 2001).

Beberapa penelitian telah menguji keadilan organisasional dengan tiga komponen, yaitu: distributif, prosedural, dan interaksional (Cohen-Carash dan Spector, 2001). Penilaian individu terkait alokasi imbalan mengacu pada keadilan distributif (Leventhal, 1976), sedangkan penilaian mengenai prosedur yang digunakan untuk menentukan alokasi tersebut mengacu pada keadilan prosedural (Cropanzano dan Greenberg, 1997). Sedangkan keadilan interaksional mengacu pada cara manajemen berperilaku kepada penerima keadilan (Cohen-Carash dan 
Spector, 2001). Apabila keadilan organisasional telah terpenuhi, maka karyawan cenderung akan merasa terpuaskan.

Kepuasan kerja merupakan bagian dari sikap yang banyak diteliti sebagai konsekuensi dari keadilan organisasional. Bagi perusahaan, kepuasan kerja berarti mereka termotivasi dan berkomitmen untuk mencapai kinerja yang tinggi. Kepuasan kerja merupakan indikator penting terkait bagaimana karyawan merasakan perlakuan organisasi. Odom et al. (1990) menyatakan bahwa kepuasan kerja pada dasarnya adalah seberapa besar perasaan positif atau negatif yang diperlihatkan karyawan terhadap karyawanannya. Kepuasan kerja berkaitan dengan penilaian afektif umum karyawan terkait karyawanan.

Penelitian Elamin dan Alomaim (2011), menyimpulkan terdapat pengaruh positif signifikan antara keadilan organisasional dengan kepuasan kerja. Demikian pula penelitian Bakhshi et al. (2009), Memarzadeh dan Mahmoudi (2010), dan AlZu'bi (2010) menyatakan keadilan organisasional berpengaruh positif signifikan terhadap kepuasan kerja. Selanjutnya Clay-Warner et al. (2005) meneliti pengaruh keadilan distributif dan prosedural terhadap kepuasan kerja menyimpulkan bahwa, kedua jenis keadilan tersebut mempunyai hubungan positif dan signifikan terhadap kepuasan kerja. Penelitian ini juga menyimpulkan keadilan prosedural merupakan prediktor yang lebih kuat dibanding distributif bagi kepuasan kerja karyawan. Whisenant dan Smucker (2006) melakukan riset hubungan keadilan organisasional dengan kepuasan kerja. Hasil penelitian yang dilakukan menunjukkan ketiga 
Lino Da Silva Saldanha, Wy. Gd. Supartha, Gd. Riana., Pengaruh Keadilan Organisasional........

dimensi keadilan organisasional (keadilan distributif, prosedural, dan interpersonal) memiliki hubungan positif dengan kepuasan kerja.

Salah satu konsekuensi kepuasan kerja karyawan adalah meningkatnya kinerja karyawan. Menurut Robbin dan Judge (2008) kepuasan kerja merupakan emosi positif yang diperoleh dari evaluasi pengalaman kerja seseorang. Kepuasan kerja berpengaruh terhadap kinerja karyawan yang akan mempengaruhi tujuan produktivitas, kualitas, dan pelayanan. Kinerja dapat diartikan sebagai hasil dari suatu proses atau karyawanan. Karena itu setiap karyawan dituntut untuk memiliki kepuasan kerja yaitu, satu rangkaian perasaan menyenangkan atau tidak menyenangkan dan emosi yang terlibat dalam sudut pandang karyawan (Davis dan Newstorm, 2002).

Penelitian Ho et al. (2009) menyatakan bahwa kepuasan kerja berpengaruh positif dan signifikan terhadap komitmen. Dijelaskan pula bahwa, baik keadilan distributif dan keadilan procedural memiliki peran penting bahkan dikatakan keduanya berpengaruh signifikan terhadap peningkatan komitmen karyawan. Cheung dan $\mathrm{Wu}$ (2012) melakukan penelitian pengaruh keadilan procedural dan distributive terhadap komitmen organisasional. Hasil penelitiannya menyimpulkan bahwa keadilan prosedural dan distributive berpengaruh secara signifikan terhadap komitmen organisasional.

Tujuan dari penelitian ini adalah untuk menganalisis signifikansi hubungan antara tiga jenis keadilan organisasi (prosedural, distributif dan interaksional) 
terhadap kepuasan kerja dan komitmen organisasional. Penelitian ini akan dilakukan pada anggota organisasi dalam Polícia Nacional De Timor-Leste (PNTL).

Berdasarkan tujuan penelitian dan hasil beberapa penelitian terdahulu dapat digambarkan kerangka konseptual penelitian pada gambar berikut.

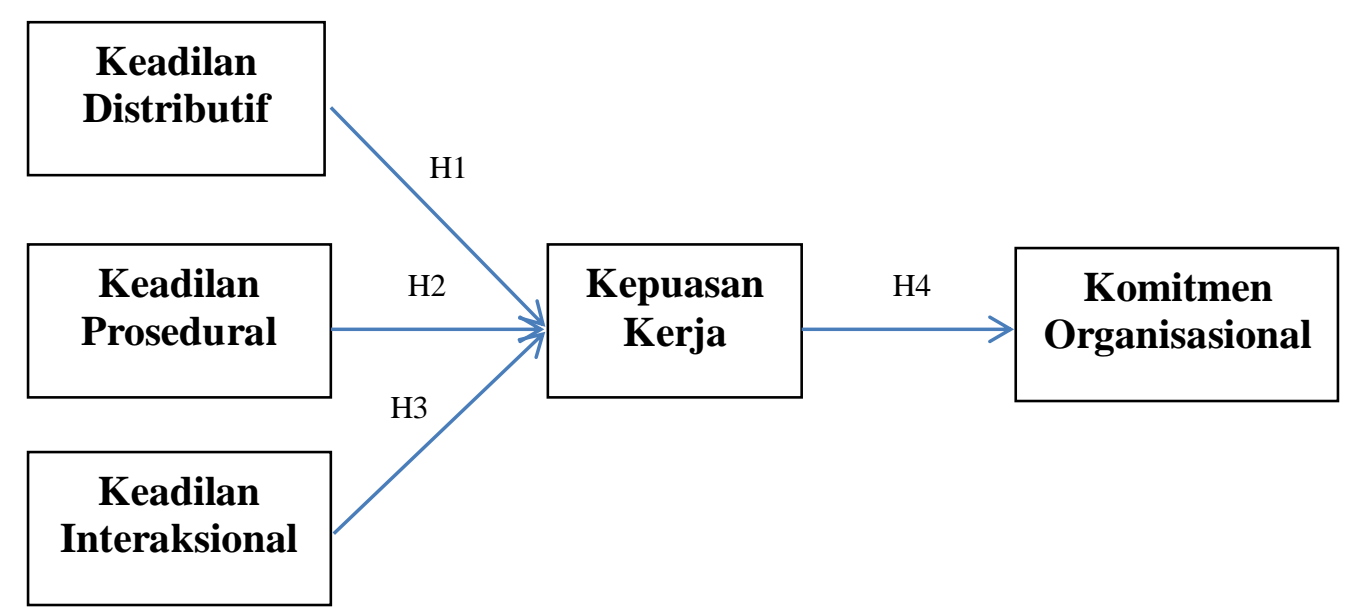

Gambar 1.

Kerangka Konseptual Penelitian

\section{HIPOTESIS}

\section{Pengaruh Keadilan organisasional Terhadap Kepuasan Kerja}

Penelitian yang dilakukan Ambrose, dan Arnaud (2005), menunjukkan bahwa keadilan organisasional berpengaruh secara positif signifikan terhadap kepuasan kerja. Penelitian yang dilakukan Putra (2014), menunjukkan bahwa keadilan organisasional berpengaruh positif pada kepuasan kerja karyawan. Menurut 
Lino Da Silva Saldanha, Wy. Gd. Supartha, Gd. Riana., Pengaruh Keadilan Organisasional........

Dailey dan Kirk, (1992), organisasi harus menjaga dan selalu memperhatikan seberapa besar rasa keadilan yang dirasakan karyawannya dan kepuasan karyawan pada pekerjaannya.

Menurut Fatimah et al. (2011), terdapat pengaruh yang signifikan dan positif dari keadilan organisasi terhadap kepuasan kerja. Selanjutnya McFarlin, dan Sweeney, (1992), menyatakan bahwa keadilan organisasional berpengaruh positif dan signifikan terhadap kepuasan kerja. Demikian juga, Nadiri dan Tanova (2010), McAuliffe et al. (2009), Zainalipour et al.(2010), Dundar dan Tabancali (2012), menyatakan bahwa keadilan organisasional berpengaruh positif signifikan terhadap kepuasan kerja.

Berdasarkan uraian tersebut diatas, maka hipotesis penelitian ini adalah sebagai berikut.

H1: Keadilan distributif berpengaruh positif signifikan terhadap kepuasan kerja

H2: Keadilan prosedural berpengaruh positif signifikan terhadap kepuasan kerja

H3: Keadilan interaksional berpengaruh positif signifikan terhadap kepuasan kerja

\section{Pengaruh Kepuasan Kerja Terhadap Komitmen Organisasional}

Menurut Kim, et al., (2005), menyatakan bahwa terdapat pengaruh yang signifikan antara keadilan distributive, keadilan prosedural dan keadilan interaksional terhadap komitmen organisasi. Dijelaskan pula bahwa Sikap kerja memiliki hubungan positif yang kuat dengan komitmen organisasi. Penelitian yang dilakukan Azeem (2010) dan Nagar, (2012), menunjukkan bahwa kepuasan kerja sebagai 
prediktor signifikan dari komitmen organisasi. Demikian pula penelitian Humborstad, dan Perry, (2011) menyimpulkan bahwa sifat pekerjaan, kepuasan gaji dan pengawasan kualitas merupakan prediktor signifikan dari komitmen organisasi. De Gieter, et al, (2011) menemukan bahwa karyawan yang sangat puas dengan atasan mereka, rekan kerja, kompensasi, kerja itu sendiri dan peluang kemajuan di perguruan tinggi dapat meningkatkan komitmen organisasi. Ho et al. (2009) dan Humborstad, dan Perry, (2011), menyatakan bahwa kepuasan kerja berpengaruh positif dan signifikan terhadap komitmen organisasional. Sejalan dengan hal tersebut adalah penelitian yang dilakukan oleh: Cheung dan Wu (2012), Yang (2012), dan Bowling \& Hammond (2008).

Berdasarkan uraian tersebut, maka hipotesis penelitian ini adalah sebagai berikut.

H4 : Kepuasan kerja berpengaruh positif signifikan terhadap komitmen organisasional

\section{METODE PENELITIAN}

Penelitian ini dilakukan pada Polícia Nacional de Timor-Leste (PNTL). PNTL adalah Kepolisian Nasional Timor-Leste yang bertanggung jawab atas keamanan dalam negeri Timor Leste di bawah Kementerian Pertahanan dan Keamanan (Ministério da Defesa e Segurança) khususnya Sekretariat Negara urusan Keamanan (Secretaria de Estado da Segurança). Pada pemerintah

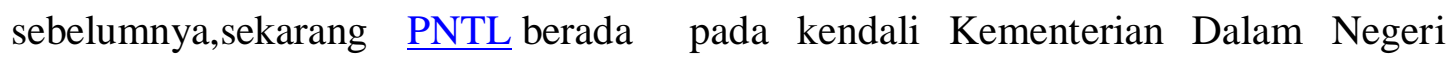


Lino Da Silva Saldanha, Wy. Gd. Supartha, Gd. Riana., Pengaruh Keadilan Organisasional........

(Ministério do Interior). Penelitian ini menggunakan sampel 115 anggota chief agent di PNTL, data dikumpulkan dengan melakukan wawancara dan penyebaran kuesioner. Data yang telah terkumpul diuji terlebih dahulu dengan uji validitas dan reliabilitas. Setelah dinyatakan valid dan reliabel, selanjutnya data yang telah terkumpul dianalisis dengan menggunakan analisis deskriptif dan analisis jalur.

Karakteristik responden yang digunakan sebagai sampel ditampailkan pada Tabel 1. Berikut.

Tabel.1

Karakteristik Responden

\begin{tabular}{ccc}
\hline \multicolumn{1}{c}{ Karakteristik } & Jumlah (staff) & $\begin{array}{c}\text { Persentase } \\
(\boldsymbol{\%})\end{array}$ \\
\hline Usia & & \\
1. $25-30$ tahun & 13 & 11,3 \\
2. $31-36$ tahun & 33 & 28,7 \\
3. $37-42$ tahun & 41 & 35,7 \\
4. $43-48$ tahun & 21 & 18,2 \\
5. $\quad 49$ tahun & 7 & 6,1 \\
Jumlah & $\mathbf{1 1 5}$ & $\mathbf{1 0 0}$ \\
Jenis Kelamin & & \\
1. Pria & 82 & 71,3 \\
2. Wanita & 33 & 28,7 \\
Jumlah & $\mathbf{1 1 5}$ & $\mathbf{1 0 0}$ \\
Pendidikan & & \\
1. SMA & 88 & 76,5 \\
2. Diploma & 1 & 0,9 \\
3. S1 & 24 & 20,9 \\
4. S2 & 2 & 1,7 \\
$\quad$ Jumlah & & \\
\hline
\end{tabular}

Sumber: Data diolah, 2015

Tabel 1. Menunjukkan karakteristik terhadap 115 responden dapat dijelaskan bahwa, mayoritas responden merupakan pria yaitu sebesar 71,3\% sedangkan responden wanita hanya sebesar $28,7 \%$. Hal tersebut menandakan cukup banyak wanita yang memiliki keinginan untuk menjadi anggota PNTL. Dilihat dari 
faktor usia, dapat diketahui bahwa paling banyak responden berusia 37 hingga 42 tahun yaitu sebesar 35,7 \%, diikuti usia 31 hingga 36 tahun sebesar 28,7\%, responden dengan umur 43 hingga 48 tahun sebesar 18,2 \%, umur 25 hingga 30 tahun sebesar $11,3 \%$, serta $6,1 \%$ sisanya memeiliki usia diatas 49 tahun. Faktor usia menunjukkan tingkat produktivitas dan kematangan dari seorang anggota PNTL. Berdasarkan distribusi usia menunjukkan bahwa sebagaian besar atau mayoritas anggota PNTL memeliki daya kerja dan produktivitas yang baik.

Berdasarkan tingkat pendidikan, dapat diketahui bahwa dominan responden anggota PNTL berpendidikan SMA sebesar 76,5\%, diikuti oleh pendidikan Strata - 1 (S1) sebanyak 20,9 \% responden, berpendidikan Strata 2 (S2) sebanyak 1,7 \%, sedangkan anggota PNTL yang berpendidikan setingkat Diploma menduduki peringkat terkecil yaitu sebanyak $0,9 \%$. Dengan mayoritas anggota PNTL sebagai responden yang berpendidikan SMA dipandang perlu untuk memberikan pendidikan dan pelatihan (trainning and development) secara berkesinambungan untuk dapat meningkatkan kemampuan serta kompetensi mereka sehingga mampu bekerja sesuai dengan visi dan misi organisasi. Disamping itu, perlu dilakukan pengembangan karir kepada para anggota PNTL yang memiliki potensi dan kemampuan untuk di assessment agar dapat mengembangkan diri menuju ke jenjang pendidikan yang lebih tinggi untuk memberikan apresiasi serta memotivasi diri. 


\section{HASIL DAN PEMBAHASAN}

\section{Deskripsi Variabel Penelitian}

Menurut Sugiyono (2010:21), untuk mendeskripsikan penilaian responden pada masing-masing instrumen penelitian perlu dilakukan suatu penggolongan jawaban responden ke dalam skala pengukuran yang telah ditetapkan pada lima kategori yaitu: sangat buruk, buruk, cukup, baik, dan sangat baik. Suatu skala pengukuran ditetapkan melalui formulai interval range dengan rumus sebagai berikut:

$$
\begin{aligned}
& \text { Interval }=\frac{\text { nilai } \text { batas terting gi }- \text { nilai batas terendah }}{\text { total nilai yang digunakan }} \\
& \text { Interval }=\frac{5-1}{5}=0,8
\end{aligned}
$$

Berdasarkan hasil perhitungan formulasi interval range maka dapat disusun kriteria pengukuran sebagai berikut:

$$
\begin{array}{rrrl}
1,00 \quad-\quad 1,80 & =\text { sangat tidak baik } \\
1,81 \quad-\quad 2,61 & =\text { tidak baik } \\
2,62-3,42 & =\text { cukup } \\
3,43 \quad-\quad 4,23 & =\text { baik } \\
4,24 \quad-\quad 5,00 & =\text { sangat baik }
\end{array}
$$


Berdasarkan hasil analisis dapat diketahui persepsi jawaban para responden atas kuesioner tersebut dan tersaji dalam Tabel 5.2.

Tabel 2

\section{Deskripsi Variabel Keadilan Distributif}

\begin{tabular}{|c|c|c|c|c|c|c|c|}
\hline \multirow{2}{*}{ Item Pertanyaan } & \multicolumn{5}{|c|}{ Jumlah Responden per skor } & \multirow{2}{*}{$\begin{array}{l}\text { Rata- } \\
\text { Rata }\end{array}$} & \multirow{2}{*}{$\begin{array}{c}\text { Ketera } \\
\text { ngan }\end{array}$} \\
\hline & 1 & 2 & 3 & 4 & 5 & & \\
\hline $\begin{array}{l}\text { Imbalan mencerminkan usaha yang } \\
\text { diberikan }\end{array}$ & 16 & 24 & 30 & 32 & 13 & 3.02 & cukup \\
\hline Imbalan sesuai dengan pekerjaan & 11 & 17 & 38 & 22 & 27 & 3.32 & cukup \\
\hline $\begin{array}{l}\text { Imbalan mencerminkan kontribusi kepada } \\
\text { organisasi }\end{array}$ & 14 & 23 & 37 & 28 & 13 & 3.03 & cukup \\
\hline $\begin{array}{l}\text { Imbalan sesuai dengan kinerja yang } \\
\text { dihasilkan }\end{array}$ & 9 & 25 & 25 & 31 & 25 & 3.33 & cukup \\
\hline \multicolumn{6}{|c|}{ Rata-rata Skor Keadilan Distributif } & 3.17 & cukup \\
\hline
\end{tabular}

Sumber: Hasil analisis

Tabel.2 menunjukkan deskripsi responden terhadap variable keadilan distributif. Hasil analisis deskriptif dapat dinyatakan sebagai bahwa keadilan distributive menjelaskan mengenai alokasi hasil-hasil yang berhubungan dengan teori ekuitas yang menjelaskan bahwa seseorang akan mendapatkan penghargaan sesuai dengan kontribusi yang diberikan. Secara keseluruhan persepsi anggota PNTL terhadap keadilan distributive dikatagorikan cukup $(3,17)$. Dapat dijelaskan bahwa para anggota PNTL belum sepenuhnya merasakan bahwa kontribusi berupa penghargaan yang diberikan belum memadai. Hal ini terlihat dari Imbalan mencerminkan usaha yang diberikan $(3,02)$ dan Imbalan mencerminkan kontribusi kepada organisasi $(3,03)$ memiliki nilai rata - rata terendah. 


\section{Tabel .3}

\section{Deskripsi Variabel Keadilan Prosedural}

\begin{tabular}{lcccccccc}
\hline \multicolumn{1}{c}{ Item Pertanyaan } & \multicolumn{1}{c}{ Jumlah Responden per skor } & $\begin{array}{c}\text { Rata- } \\
\text { Rata }\end{array}$ & $\begin{array}{c}\text { Ketera } \\
\text { ngan }\end{array}$ \\
\hline $\begin{array}{l}\text { Kesempatan yang diberikan untuk } \\
\text { mengungkapkan pandangan }\end{array}$ & 1 & 2 & 3 & 4 & 5 & & \\
$\begin{array}{l}\text { Perlakuan yang sama terhadap semua } \\
\text { anggota }\end{array}$ & 12 & 19 & 29 & 31 & 25 & 3.37 & cukup \\
$\begin{array}{l}\text { Tidak ada anggota PNTL yang } \\
\text { diistimewakan }\end{array}$ & 14 & 19 & 26 & 28 & 28 & 3.32 & cukup \\
$\begin{array}{l}\text { Keputusan yang dibuat berdasarkan } \\
\text { informasi akurat }\end{array}$ & 5 & 17 & 27 & 41 & 25 & 3.56 & baik \\
$\begin{array}{l}\text { Peraturan PNTL menjunjung tinggi } \\
\text { standar moral dan etika }\end{array}$ & 4 & 16 & 21 & 32 & 42 & 3.8 & baik \\
$\begin{array}{l}\text { Peraturan-peraturan PNTL dibuat } \\
\text { berdasarkan informasi yang akurat }\end{array}$ & 4 & 13 & 25 & 36 & 37 & 3.77 & baik \\
\multicolumn{1}{c}{ Rata-rata Skor Keadilan Prosedural } & & & & $\mathbf{3 . 5 2}$ & baik \\
\hline
\end{tabular}

Sumber: Hasil analisis

Keadilan presedural berfokus pada perasaan adil yang dirasakan oleh para karyawan terkait dengan pemberian alokasi kepada karyawan dalam prosedurprosedur yang ada di dalam proses pengambilan keputusan. Secara keseluruhan persepsi anggota PNTL terhadap keadilan presedural dinyatakan baik $(3,52)$. Namun demikian, masih terdapat indicator yang memiliki nilai lebih rendah dari rata-rata, dan bahkan dipersepsikan cukup oleh staff PNTL. Indicator tersebut adalah: atasan memperlakukan saya dengan hormat $(3,33)$ dan Tidak ada anggota PNTL yang diistimewakan (3,32). Indikator yang mempunyai rata-rata skor tertinggi pada keadilan prosedural adalah peraturan PNTL menjunjung tinggi standar moral dan etika sebesar 3,80. Peraturan-peraturan PNTL dibuat berdasarkan informasi yang akurat $(3,77)$ dan keputusan yang dibuat berdasarkan informasi akurat $(3,56)$. 
Tabel .4

Deskripsi Variabel Keadilan Interaksional

\begin{tabular}{|c|c|c|c|c|c|c|c|}
\hline \multirow[t]{2}{*}{ Item Pertanyaan } & \multicolumn{5}{|c|}{ Jumlah Responden per skor } & \multirow[t]{2}{*}{$\begin{array}{l}\text { Rata- } \\
\text { Rata }\end{array}$} & \multirow[t]{2}{*}{$\begin{array}{l}\text { Keteran } \\
\text { gan }\end{array}$} \\
\hline & 1 & 2 & 3 & 4 & 5 & & \\
\hline $\begin{array}{l}\text { Atasan memperlakukan saya dengan } \\
\text { sopan }\end{array}$ & 10 & 14 & 26 & 35 & 30 & 3.53 & baik \\
\hline $\begin{array}{l}\text { Atasan memperlakukan saya dengan } \\
\text { hormat }\end{array}$ & 6 & 18 & 30 & 41 & 20 & 3.44 & baik \\
\hline $\begin{array}{l}\text { Atasan memahami diri untuk tidak } \\
\text { berkomentar yang tidak pantas }\end{array}$ & 10 & 21 & 33 & 28 & 23 & 3.29 & cukup \\
\hline Atasan jujur dalam berkomunikasi & 4 & 14 & 37 & 33 & 27 & 3.57 & baik \\
\hline $\begin{array}{l}\text { Atasan menjelaskan peraturan / prosedur } \\
\text { secara menyeluruh }\end{array}$ & 2 & 22 & 28 & 31 & 32 & 3.60 & baik \\
\hline $\begin{array}{l}\text { Penjelasan atasan terkait peraturan / } \\
\text { prosedur masuk akal }\end{array}$ & 2 & 17 & 34 & 35 & 27 & 3.59 & baik \\
\hline \multicolumn{6}{|c|}{ Rata-rata Skor Keadilan Interaksional } & 3.50 & baik \\
\hline
\end{tabular}

Sumber : Hasil analisis.

Keadilan interaksional mencerminkan nilai keadilan yang dirasakan karyawan karena adanya proses interaksi dengan pihak lain dalam organisasi baik dari pimpinan maupun rekan sekerja. Secara keseluruhan persepsi anggota PNTL terhadap keadilan interaksional adalah baik $(3,50)$. Namun demikian, terdapat persepsi anggota PNTL yang menyatakan cukup yaitu atasan menahan diri untuk tidak berkomentar yang tidak pantas $(3,29)$. Selanjutnya, persepsi anggota PNTL tertinggi terhadap keadilan intreaksional adalah atasan menjelaskan peraturan /prosedur secara menyeluruh $(3,60)$, penjelasan atasan terkait peraturan/ prosedur masuk akal $(3,59)$, Atasan jujur dalam berkomunikasi $(3,57)$, Atasan memperlakukan saya secara sopan $(3,53)$ dan Atasan memperlakukan saya dengan hormat $(3,44)$. 
Tabel .5

\section{Deskripsi Variabel Kepuasan Kerja}

\begin{tabular}{|c|c|c|c|c|c|c|c|}
\hline \multirow{3}{*}{ Item Pertanyaan } & \multicolumn{5}{|c|}{ Jumlah Responden } & \multirow{3}{*}{$\begin{array}{l}\text { Rata } \\
\text { rata }\end{array}$} & \multirow{3}{*}{$\begin{array}{l}\text { Kete } \\
\text { rangan }\end{array}$} \\
\hline & \multicolumn{5}{|c|}{ per skor } & & \\
\hline & 1 & 2 & 3 & 4 & 5 & & \\
\hline Saya merasa puas dengan pekerjaan saya & 9 & 11 & 23 & 33 & 39 & 3.71 & baik \\
\hline Puas dengan imbalan finansial yang diterima & 12 & 32 & 23 & 23 & 25 & 3.15 & cukup \\
\hline $\begin{array}{l}\text { Saya puas dengan kesempatan untuk maju dan } \\
\text { mengembangkan diri }\end{array}$ & 9 & 19 & 22 & 32 & 33 & 3.53 & baik \\
\hline Saya puas dengan supervise yang dilakukan & 7 & 13 & 33 & 35 & 27 & 3.54 & baik \\
\hline Saya puas dengan keterlibatan rekan kerja & 5 & 12 & 29 & 35 & 34 & 3.70 & baik \\
\hline \multicolumn{6}{|c|}{ Rata-rata Skor Kepuasan Kerja (Y1) } & 3.53 & baik \\
\hline
\end{tabular}

Sumber : Lampiran 5

Berdasarkan Tabel. 5. dapat dijelaskan bahwa kepuasan kerja mengacu pada perasaan yang bersifat subjektif tentang seberapa mampu organisasi memenuhi keinginan para karyawan. Hasil analisis deskriptif menunjukkan bahwa secara keseluruhan kepuasan kerja anggota PNTL dinyatakan baik. Hanya saja masih ada persepsi anggota PNTL yang merasa bahwa Kepuasan dengan imbalan finansial yang diterima belum memadai $(3,15)$. Indikator yang mempunyai rata-rata skor tertinggi pada konstruk kepuasan kerja adalah merasa puas dengan pekerjaan $(3,71)$, puas dengan keterlibatan rekan kerja $(3,70)$, puas dengan supervisi yang dilakukan $(3,54)$, puas dengan kesempatan untuk maju dan mengembangkan diri $(3,53)$. 
Tabel .6

Deskripsi Variabel Komitmen Organisasional

\begin{tabular}{|c|c|c|c|c|c|c|c|}
\hline \multirow{3}{*}{ Item Pertanyaan } & \multicolumn{5}{|c|}{ Jumlah Responden } & \multirow{3}{*}{$\begin{array}{l}\text { Rata } \\
\text { rata }\end{array}$} & \multirow{3}{*}{$\begin{array}{l}\text { Kete } \\
\text { rangan }\end{array}$} \\
\hline & \multicolumn{5}{|c|}{ per skor } & & \\
\hline & 1 & 2 & 3 & 4 & 5 & & \\
\hline $\begin{array}{l}\text { Saya merasa masalah yang dihadapi perusahaan } \\
\text { adalah juga masalah saya }\end{array}$ & 15 & 13 & 24 & 24 & 39 & 3.51 & baik \\
\hline Mempunyai rasa memiliki terhadap PNTL & 12 & 20 & 19 & 28 & 36 & 3.49 & baik \\
\hline Merasa terikat secara emosional dengan PNTL & 14 & 17 & 27 & 27 & 30 & 3.37 & cukup \\
\hline PNTL sangat berarti bagi karier saya & 9 & 16 & 21 & 25 & 44 & 3.69 & baik \\
\hline Merasa menjadi bagian dari keluarga PNTL & 8 & 11 & 16 & 35 & 45 & 3.85 & baik \\
\hline Saya berniat mencari pekerjaan lain & 23 & 21 & 22 & 27 & 22 & 3.03 & cukup \\
\hline Saya berniat untuk tetap bekerja di PNTL & 6 & 10 & 21 & 22 & 56 & 3.97 & baik \\
\hline \multicolumn{6}{|c|}{ Rata-rata Skor Komitmen Organisasional } & 3.56 & baik \\
\hline
\end{tabular}

Sumber: Hasil analisis

Berdasarkan Tabel. 6 dapat dijelaskan bahwa komitmen organisasional mengacu pada suatu keadaan seorang karyawan untuk memihak organisasi serta tujuan-tujuan dan keinginannya mempertahankan keanggotaan dalam organisasi tersebut. Berdasarkan analisis deskriptif tingkat komitmen organisasional anggota PNTL dinyatakan baik dengan nilai rata - rata $(3,56)$. Indikator yang mempunyai rata-rata skor tertinggi adalah mereka berniat untuk tetap bekerja di PNTL dengan rata - rata $(3,97)$. Hal ini berarti bahwa komitmen mereka terhadap organisasi sudah baik. Pernyataan tersebut didukung oleh pernyataan lain bahwa niat mereka untuk mencari pekerjaan lain yang rendah $(3,02)$. Hal tersebut menggambarkan secara 
Lino Da Silva Saldanha, Wy. Gd. Supartha, Gd. Riana., Pengaruh Keadilan Organisasional........

keseluruhan bahwa tingkat komitmen anggota PNTL terhadap organisasi dapat dikatagorikan baik.

\section{HASIL ANALISIS JALUR}

Dalam analisis jalur diawali dengan pemeriksaan asumsi bahwa hubungan antar variabel adalah linier dan aditif. Hasil analisis jalur dijelaskan dari hasil analisis regresi. Model tersebut juga dapat dinyatakan dalam bentuk persamaan atau diagram jalur sehingga ada yang menamakan sistem persamaan simultan, atau juga ada yang menyebut model struktural.

\section{Substruktur 1}

$$
\mathrm{Y} 1=\beta_{1} \mathrm{X} 1+\beta_{2} \mathrm{X} 2+\beta_{3} \mathrm{X} 3+\mathrm{e}_{1}
$$

Hasil analisis regresi pada persamaan substruktur 1 dapat dilihat pada Table berikut.

\section{Tabel 7}

Hasil Analisis Jalur Pada substruktur 1

\begin{tabular}{|c|c|c|c|c|c|c|c|c|c|c|c|c|c|}
\hline \multicolumn{14}{|c|}{ Coefficients $^{2}$} \\
\hline \multirow[b]{2}{*}{ Model } & & \multicolumn{2}{|c|}{$\begin{array}{l}\text { Unstandardized } \\
\text { Coefficients }\end{array}$} & \multirow{2}{*}{$\begin{array}{c}\text { Standardized } \\
\text { Coefficients }\end{array}$} & \multirow[b]{2}{*}{$t$} & \multirow[b]{2}{*}{ Sig. } & \multicolumn{2}{|c|}{$95 \%$ Confidence Interval for B } & \multicolumn{3}{|c|}{ Correlations } & \multicolumn{2}{|c|}{ Collinearity Statistics } \\
\hline & & $B$ & Std. Error & & & & Lower Bound & Upper Bound & Zero-order & Partial & Part & Tolerance & VIF \\
\hline 1 & (Constant) & .000 & .051 & & .000 & 1.000 & -101 & .101 & & & & & \\
\hline & Keadilan Distributif & .295 & .077 & .295 & 3.830 & .000 & .142 & .447 & .729 & .342 & .196 & .443 & 2.257 \\
\hline & Keadilan Prosedural & .170 & .082 & .170 & 2.073 & .040 & .008 & .333 & .717 & .193 & .106 & .389 & 2.574 \\
\hline & Keadilan interaksionnal & .472 & .077 & .472 & 6.141 & .000 & .320 & .624 & .788 & .504 & .315 & .445 & 2.248 \\
\hline
\end{tabular}

a. Dependent Variable: Kepuasan

Berdasarkan hasil analisis jalur pada substruktur 1 dapat dibuat persamaan structural yang terbentuk sebagai berikut. 
$\mathrm{Y} 1=\beta_{1} \mathrm{X}_{1}+\beta_{2} \mathrm{X}_{2}+\beta_{3} \mathrm{X}_{3}+\mathrm{e}_{1}$

$\mathrm{Y} 1=0,295 \mathrm{X}_{1}+0,170 \mathrm{X}_{2}+0,472 \mathrm{X}_{3}+\mathrm{e} 1$

F hitung $=90,001$

$$
\begin{aligned}
\mathrm{R}^{2}=0,701 & \\
\text { Error Term }\left(e_{1}\right) & =\sqrt{1-\mathrm{R}^{2}} \\
& =\sqrt{1-0,701^{2}} \\
& =\sqrt{1-0,491} \\
& =\sqrt{0,508} \\
& =0,712
\end{aligned}
$$

\begin{tabular}{|c|c|c|c|c|c|c|c|c|c|c|c|c|c|}
\hline \multirow[b]{2}{*}{ Model } & & \multicolumn{2}{|c|}{$\begin{array}{c}\text { Unstandardized } \\
\text { Coefficients }\end{array}$} & \multirow{2}{*}{$\begin{array}{c}\text { Standardized } \\
\text { Coefficients }\end{array}$} & \multirow[b]{2}{*}{ t } & \multirow[b]{2}{*}{ Sig. } & \multicolumn{2}{|c|}{$95 \%$ Confidence Interval for B } & \multicolumn{3}{|c|}{ Correlations } & \multicolumn{2}{|c|}{ Collinearity Statistics } \\
\hline & & $\mathrm{B}$ & Std. Error & & & & Lower Bound & Upper Bound & Zero-order & Partial & Part & Tolerance & $V \mid F$ \\
\hline 1 & (Constant) & .000 & .058 & & .000 & 1.000 & -114 & .114 & & & & & \\
\hline & Kepuasan & .788 & .058 & .788 & 13.612 & .000 & .673 & .903 & .788 & .788 & .788 & 1.000 & 1.000 \\
\hline
\end{tabular}

Tabel 8

Hasil analisis regresi substruktur 2

Coefficients ${ }^{2}$

a. Dependent Variable: Komitmen

\section{Substruktur 2}

$\mathrm{Y} 2=\beta_{4} \mathrm{Y} 1+\mathrm{e}_{2}$

$\mathrm{Y} 2=0,788 \mathrm{Y}_{1}+\mathrm{e} 2$

$\mathrm{F}$ hitung $=185,276$

$\mathrm{R}^{2}=0,621$ 


$$
\begin{aligned}
\operatorname{Error} \operatorname{Term}\left(e_{1}\right) & =\sqrt{1-\mathrm{R}^{2}} \\
& =\sqrt{1-0,621^{2}} \\
& =\sqrt{1-0,386} \\
& =\sqrt{0,614} \\
& =0,784
\end{aligned}
$$

Tahap berikutnya dalam analisis jalur adalah pemeriksaan validitas model terdapat dua indikator validitas model di dalam analisis jalur yaitu koefisien determinasi total dan theory triming. Koefisien determinasi total merupakan total keragaman data. Untuk menghitung koefisien determinasi total dapat digunakan persamaan sebagai berikut:

$$
\begin{aligned}
& \mathrm{R}^{2} \mathrm{~m}=1-\left(\mathrm{e}_{1}\right)^{2}\left(\mathrm{e}_{2}\right)^{2} \ldots \ldots \ldots . . \\
& \mathrm{R}^{2} \mathrm{~m}=1-(0,712)^{2}(0,784)^{2} \\
& \mathrm{R}^{2} \mathrm{~m}=1-(0,507)(0,615) \\
& \mathrm{R}^{2} \mathrm{~m}=0,688
\end{aligned}
$$

Dari hasil perhitungan koefisien determinasi total diperoleh nilai sebesar $\left(\mathrm{R}^{2} \mathrm{~m}=\right.$ 0,688). Hasil tersebut berarti bahwa keragaman data dapat dijelaskan oleh model sebesar 68,80\% atau dengan kata lain variasi nilai yang terkandung di dalam data 
dapat menjelaskan model yang digunakan sebesar 68,80\%. Sisanya sebesar 31,20\% dijelaskan oleh variable lain yang tidak dianalisis dalam model dan error.

\section{HASIL PENGUJIAN HIPOTESIS}

Hasil perhitungan analisis jalur mendapatkan hasil model hubungan antar variabel sebagai berikut.

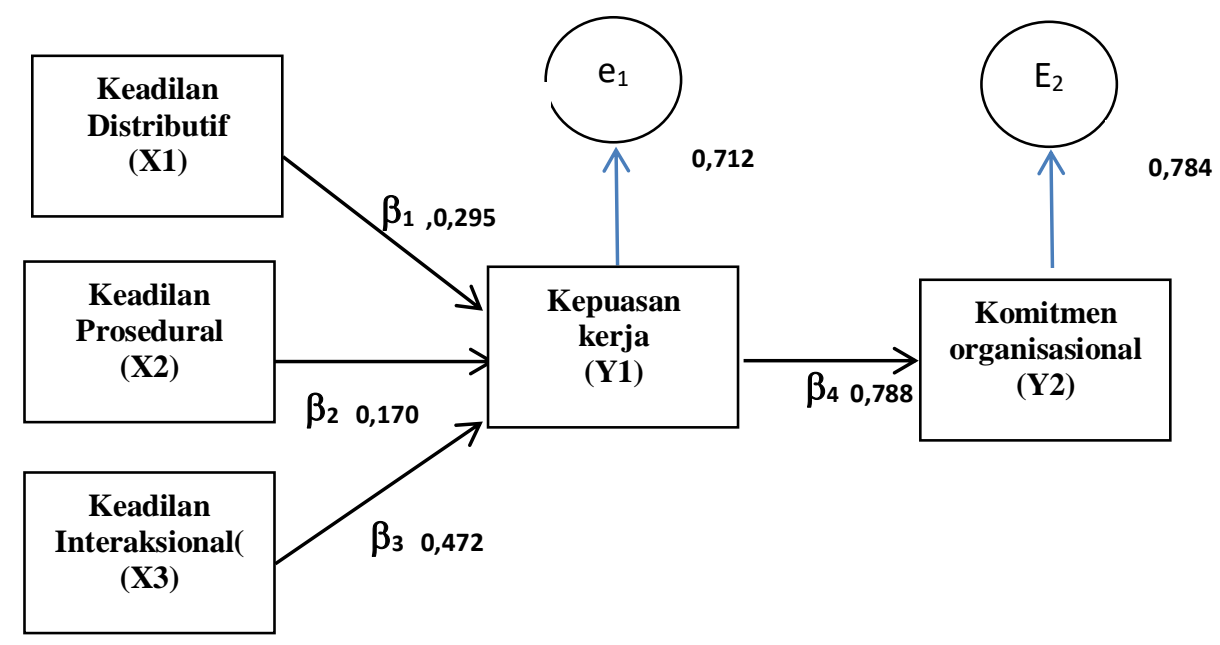

Gambar 2

Hasil Analisis Jalur

Pengujian hipotesis dilakukan dengan uji t (t-test) pada masing-masing jalur pengaruh antara variabel dependen dengan variabel independen. Hasil pengujian hipotesis dengan menggunakan analisis jalur tersebut dapat dijelaskan sebagai berikut.

1) Hipotesis 1: Keadilan distributif berpengaruh positif signifikan terhadap kepuasan kerja. Hasil analisis jalur dengan menggunakan model regresi 
Lino Da Silva Saldanha, Wy. Gd. Supartha, Gd. Riana., Pengaruh Keadilan Organisasional........

mendapatkan hasil koefisien $\beta 1$ (positif) sebesar 0,295 dengan $t$ statistic sebesar 3,830, dengan demikian hipotesis 1 diterima. Hal ini berarti bahwa semakin baik keadilan distributive, maka kepuasan kerja staff PNTL akan semakin meningkat.

2) Hipotesis 2: Keadilan prosedural berpengaruh positif signifikan terhadap kepuasan kerja. Hasil analisis jalur dengan menggunakan model regresi mendapatkan hasil koefisien $\beta 2$ (positif) sebesar 0,170 dengan $\mathrm{t}$ statistic sebesar 2,073, dengan demikian hipotesis 2 diterima. Hal ini berarti bahwa semakin baik keadilan prosedural, maka kepuasan kerja staff PNTL akan semakin meningkat.

3) Hipotesis 3: Keadilan interaksional berpengaruh positif signifikan terhadap kepuasan kerja. Hasil analisis jalur dengan menggunakan model regresi mendapatkan hasil koefisien $\beta 3$ (positif) sebesar 0,472 dengan $t$ statistic sebesar 6,141, dengan demikian hipotesis 3 diterima. Hal ini berarti bahwa semakin baik keadilan interaksional, maka kepuasan kerja staff PNTL akan semakin meningkat.

4) Hipotesis 4: Kepuasan kerja berpengaruh positif signifikan terhadap komitmen organisasional. Hasil analisis jalur dengan menggunakan model regresi mendapatkan hasil koefisien $\beta 4$ (positif) sebesar 0,788 dengan $\mathrm{t}$ statistic sebesar 13,612, dengan demikian hipotesis 4 diterima. Hal ini berarti bahwa semakin tinggi kepuasan kerja yang dirasakan oleh staff PNTL, maka komitmen organisasional staff PNTL akan semakin meningkat. 


\section{PEMBAHASAN}

\section{Pengaruh Keadilan Distributif Terhadap Kepuasan Kerja}

Hasil analisis data menunjukkan bahwa keadilan distributif berpengaruh positif signifikan terhadap kepuasan kerja. Ini artinya keadilan distributif yang diukur melalui pemberian imbalan yang sesuai dengan usaha yang dilakukan, imbalan yang dinyatakan sesuai dengan kelayakan, mencerminkan kontribusi organisasi, dan imbalan yang berbasis kinerja terbukti mampu meningkatkan kepuasan kerja.

Temuan ini dapat diartikan bahwa Imbalan sesuai dengan kinerja yang dihasilkan, imbalan yang sesuai dengan tingkat pekerjaan, imbalan mencerminkan usaha yang diberikan, dan imbalan yang diberikan sesuai dengan kontribusi terhadap organisasi mampu memberikan kontribusi signifikan terhadap peningkatan kepuasan kerja anggota PNTL. Dengan demikian keadilan procedural yang dirasakan oleh para anggota PNTL terbukti mampu memberikan rasa puas dengan pekerjaan, puas dengan keterlibatan rekan kerja.

Hasil penelitian ini sesuai dengan hasil beberapa penelitian yang telah dilakukan oleh beberapa peneliti sebelumnya bahwa keadilan distributif berpengaruh positif signifikan terhadap kepuasan kerja. Penelitian McFarlin dan Sweeney (1992) pada industri perbankan menemukan keadilan distributif merupakan prediktor kuat dibanding keadilan prosedural dalam mempengaruhi kepuasan kerja. Demikian pula penelitian Cohen dan Spector (2001) mengungkapkan keadilan distributif merupakan prediktor yang lebih kuat dibanding keadilan prosedural dan interaksional. Penelitian 
Lino Da Silva Saldanha, Wy. Gd. Supartha, Gd. Riana., Pengaruh Keadilan Organisasional........

lain yang menemukan signifikansi pengaruh keadilan distributif terhadap kepuasan kerja antara lain dilakukan oleh Nadiri dan Tanova (2010), McAuliffe et al. (2009) pada tenaga kesehatan, Zainalipour et al.(2010), dan Dundar dan Tabancali (2012) pada guru sekolah dasar.

\section{Pengaruh Keadilan Prosedural Terhadap Kepuasan Kerja}

Hasil analisis menunjukkan bahwa keadilan procedural berpengaruh positif signifikan terhadap kepuasan kerja. Ini artinya keadilan procedural yang diukur diantaranya dengan: kesempatan yang diberikan untuk mengungkapkan pandangan, perlakuan yang sama terhadap semua anggota, keputusan yang dibuat berdasarkan informasi akurat terbukti mampu meningkatkan kepuasan kerja staff PNTL.

Temuan ini dapat dijelaskan bahwa Peraturan-peraturan PNTL yang dibuat berdasarkan informasi yang akurat, peraturan PNTL yang mencerminkan menjunjung tinggi standar moral dan etika, dan keputusan yang dibuat berdasarkan informasi akurat mampu memberikan sumbangan penting dalam peningkatan kepuasan kerja anggota PNTL. Dengan demikian keadilan distributif yang dirasakan oleh para anggota PNTL terbukti mampu memberikan rasa puas dengan pekerjaan, puas dengan keterlibatan rekan kerja dan puas dengan kesempatan untuk maju dan mengembangkan diri.

Hasil temuan penelitian ini sesuai dengan penelitian yang telah dilakukan oleh beberapa peneliti seperti; Masterson et al.(2000), dan Lambert (2007) yang 
menyimpulkan bahwa keadilan prosedural merupakan prediktor kuat untuk membangun kepuasan kerja. Semakin baik keadilan prosedural yang dirasakan, maka perasaan karyawan terhadap pekerjaannya akan semakin meningkat. Hasil penelitian yang menyimpulkan pengaruh positif signifikan keadilan prosedural dilakukan antara lain oleh: Cohen dan Spector (2001), Nadiri dan Tanova (2010), McAuliffe et al. (2009), Zainalipour et al.(2010), Dundar dan Tabancali (2012).

\section{Pengaruh Keadilan Interaksional Terhadap Kepuasan Kerja}

Hasil analisis data menunjukkan bahwa keadilan interaksional berpengaruh positif signifikan terhadap kepuasan kerja. Hal ini berarti bahwa keadilan interaksional yang diukur dengan: atasan memperlakukan dengan cara yang sopan dan hormat, atasan menjelaskan peraturan /prosedur secara menyeluruh dan masuk akal, dan atasan menahan diri untuk tidak berkomentar yang tidak pantas terbukti mampu meningkatkan kepuasan kerja staff PNTL.

Temuan ini dapat dijelaskan bahwa atasan yang mampu menjelaskan peraturan / prosedur secara menyeluruh, penjelasan atasan terkait dengan peraturan / prosedur yang masuk akal, dan atasan yang memperlakukan bawahan dengan sopan dan jujur dalam berkomunikasi mampu memberikan sumbangan penting dalam membentuk kepuasan kerja anggota PNTL. Dengan demikian keadilan interaksional yang dirasakan oleh para anggota PNTL terbukti mampu memberikan rasa puas dengan 
Lino Da Silva Saldanha, Wy. Gd. Supartha, Gd. Riana., Pengaruh Keadilan Organisasional........

pekerjaan, puas dengan keterlibatan rekan kerja dan puas dengan kesempatan untuk maju dan mengembangkan diri.

Hasil penelitian ini sejalan dengan penelitian Masterson et al. (2000) yang menyatakan bahwa keadilan interaksional berpengaruh signifikan terhadap kepuasan kerja. Beberapa hasil penelitian lain oleh: Cohen-Carash dan Spector (2001), Nadiri dan Tanova (2010), McAuliffe et al. (2009), Zainalipour et al. (2010), dan Dundar dan Tabancali (2012), menyimpulkan bahwa keadilan interaksional berpengaruh positip signifikan terhadap kepuasan kerja.

\section{Pengaruh Kepuasan Kerja Terhadap Komitmen Organasisional.}

Hasil analisis data menunjukkan bahwa kepuasan kerja berpengaruh positif signifikan terhadap omitmen organisasional. Hal ini berarti bahwa kepuasan kerja yang diukur dengan: kepuasan atas gaji yang diterima, supervise, pengembangan diri, dan kepuasan atas interaksi yang dilakukan dalam organisasi terbukti mampu meningkatkan komitmen organisasional staff PNTL.

Hasil temuan ini dapat dijelaskan bahwa rasa puas dengan pekerjaan, puas dengan keterlibatan rekan kerja dan puas dengan kesempatan untuk maju dan mengembangkan diri mampu memberikan sumbangan penting dalam membentuk komitmen organisasional anggota PNTL. Dengan demikian kepuasan kerja yang dirasakan oleh para anggota PNTL terbukti mampu memberikan kontribusi positip terhadap komitmen mereka terhadap organisasi. 
Hasil penelitian ini sesuai dengan penelitian yang dilakukan Azeem (2010) dan Nagar, (2012), bahwa kepuasan kerja sebagai prediktor signifikan dari komitmen organisasional. Penelitian Humborstad dan Perry, (2011), De Gieter, et al, (2011) bahwa karyawan yang puas dengan atasan mereka, rekan kerja, kompensasi, pekerjaannya, dan peluang kemajuan dapat meningkatkan komitmen organisasi. Ho et al. (2009), Humborstad dan Perry, (2011), menyimpulkan kepuasan kerja berpengaruh positif dan signifikan terhadap komitmen organisasional. Demikian pula penelitian: Cheung dan Wu (2012), Yang (2012), Bowling dan Hammond (2008).

\section{SIMPULAN DAN SARAN}

Berdasarkan permasalahan, tujuan dan hipotesis penelitian serta hasil analisis yang telah dilakukan sebelumnya dapat diambil simpulan sebagai berikut. Keadilan distributif berpengaruh positif signifikan terhadap kepuasan kerja staff PNTL. Hal ini berarti bahwa semakin baik penerapan keadilan distributif pada PNTL, maka kepuasan kerja staff PNTL akan semakin meningkat. Keadilan procedural berpengaruh positif signifikan terhadap kepuasan kerja. Berarti bahwa perasaan adil yang dirasakan oleh para karyawan terkait dengan pemberian alokasi kepada karyawan dalam prosedur-prosedur yang ada di dalam proses pengambilan keputusan mampu meningkatkan kepuasan kerja staff PNTL. Keadilan interaksional berpengaruh positif signifikan terhadap kepuasan kerja. Hal ini berarti bahwa nilai keadilan yang dirasakan karyawan karena adanya proses interaksi dengan pihak lain 
Lino Da Silva Saldanha, Wy. Gd. Supartha, Gd. Riana., Pengaruh Keadilan Organisasional........

dalam organisasi baik dari pimpinan maupun rekan sekerja akan meningkatkan kepuasan kerja staff PNTL. Kepuasan kerja berpengaruh positif signifikan terhadap komitmen organisasional. Hal ini berarti bahwa semakin tinggi tingkat kepuasan kerja, maka komitmen organisasional staff PNTL akan semakin meningkat.

Berdasarkan kesimpulan diatas, maka dapat disampaikan beberapa saran sebagai berikut. Diperlukan adanya upaya - upaya dari PNTL untuk meningkatkan keadilan distributif seperti: merancang imbalan yang lebih sesuai dengan pekerjaan dan kinerja yang dihasilkan serta menyesuaikan imbalan yang diberikan sesuai dengan jenis pekerjaan. Memberikan kesempatan yang lebih luas kepada Staff PNTL untuk mengungkapkan pandangannya terkait dengan aktivitas organisasi, memberikan perlakuan yang sama, dan menghindari adanya anggota PNTL yang diistimewakan. Mengurangi adanya arahan dari atasan dan menahan diri untuk tidak berkomentar yang kurang berkenan di hati para staff PNTL. Melakukan evaluasi terhadap imbalan finansial yang diberikan kepada staff PNTL apakah sudah sesuai dengan system penilaian kinerja. Hal ini disebabkan karena staff PNTL mempersepsikan bahwa imbalan finansial yang diterima belum dipandang memadai. Meningkatkan keterikatan secara emosional antara staff PNTL dengan organisasi PNTL. Hal ini dapat dilakukan dengan beberapa saran yang telah diuraikan diatas. 


\section{IMPLIKASI PENELITIAN}

Hasil penelitian ini diharapkan mampu memperkaya beberapa hasil penelitian terdahulu terkait dengan pengaruh keadilan organisasional (keadilan distributive, procedural, dan interaksional) terhadap kepuasan kerja dan komitmen organisasional. Disamping itu, penelitian ini telah memberikan bukti yang konsisten hubungan antar variable yang dianalisis. Penelitian ini secara empiris telah membuktikan bahwa keadilan organisasional berpengaruh positif signifikan terhadap kepuasan kerja. Hasil analisis menunjukkan bahwa, meskipun para staff PNTL mempersepsikan bahwa mereka belum mendapatkan keadilan distributif yang baik, namun secara keseluruhan keadilan procedural dan keadilan intreaksional mampu memberikan sumbangan berharga di dalam membangun kepuasan para staff PNTL. Oleh karena itu PNTL seharusnya mulai melakukan evaluasi terhadap kebijakan terkait dengan pelaksanaan keadilan organisasional agar para staff PNTL merasa bagian dari organisasi. Polícia Nacional de Timor-Leste (PNTL) melakukan evaluasi terhadap sistem reward yang telah diterapkan mengingat para staff PNTL merasa bahwa mereka belum puas dengan reward yang diterima saat ini. Sistem reward dimaksud apakah nantinya mengarah ke reward berbasis kinerja sehingga karyawan mendapatkan reward sesuai dengan beban kerja yang diemban. Dengan sistem reward berbasis kinerja diharapkan mampu membangun komitmen organisasional staff PNTL sehingga mereka menjadi lebih terikat secara emosional dengan PNTL. 


\section{REFERENSI}

Al-Zu'bi, H.A., 2010. A Study Of Relationship Between Organizational Justice And Job Satisfaction. International Journal of Business and Management, Vol. 5, No. 12 , p. $102-109$.

Azeem, Syed Mohammad. 2010. Job Satisfaction and Organizational Commitment Among Employees in the Sultanate of Oman. Journal of Psychology, Vol.1, No. 1, pg 295-299.

Antoncic, J.A., \& Antoncic, B., 2011. Employee Satisfaction Intrapreneurship And Firm Growth : A Model. Industrial Management And Data Systems, Vol. 111, No. 4, p. $589-607$.

Ambrose, M.L., \& Arnaud, A., 2005. Are Procedural Justice And Distributive Justice Conceptually Distinct?, Handbook Of Organizational Justice. Lawrence Erlbaum Associates, Inc.

Aquino, K., Lewis, M.U., \& Bradfield, M., 1999. Justice Construct, Negative Affectivity, \& Employee Deviance : A Proposes Model \& Empirical Test. Journal Of Organizational Behavior, Vol. 20, p. 1073 - 1091.

Bakhshi, A., Kumar, K., \& Rani, E., 2009. Organizational Justice Perceptions As Predictor Of Job Satisfaction And Organization Commitment. International Journal Of Business And Management, Vol. 4, No. 9, p. 145-154.

Bowling, N. A. \& Hammond, G. D., 2008.A Meta-Analytic Examination Of The Construct Validity Of The Michigan Organizational Assessment Questionnaire Job Satisfaction Subscale. Journal of Vocational Behavior, No. 73, p. 63 - 77.

Cheung, M. F. Y. \& Wu, W-P, 2012.Leader-Member Exchange \& Employee Work Outcomes In Chinese Firms: The Mediating Role Of Job Satisfaction. Asia Pacific Business Review, Vol. 18, No. 1, p. 65 - 81 .

Clay-Warner, J., Reynolds, J., \& Roman, P., 2005. Organizational Justice And Job Satisfaction: A Test of Three Competing Models. Social Justice Research, Vol. 18, No. 4, p. $391-409$.

Cohen-Carash, Y., \& Spector, P.E., 2001.The Role of Justice in Organizations :A Meta-Analysis. Journal Of Organizational Behavior and Human Decision Processes, Vol. 86 No. 2, p. $278-321$.

Colquitt, J.A., \& Shaw, J.C., 2005. How Should Organizational Justice Be Measured ?, Handbook Of Organizational Justice. Lawrence Erlbaum Associates, Inc. 
Colquitt, J.A., 2001. On The Dimensionality Of Organizational Justice : A Construct Validation Of Measure. Journal Of Applied Psychology, Vol. 86, No. 3, p. $386-$ 400.

Colquitt, J.A., Wesson, M.J., Porter, C.O.L.H., Conlon, D.E., \&Ng, K.Y., 2001. Justice At The Millenium : A Meta-Analytic Review Of 25 Years Of Organizational Justice Research. Journal Of Applied Psychology, Vol. 86, No. 3, p. $425-445$.

Coomber, B. \& Barriball, K. L., 2007. Impact Of Job Satisfaction Components On Intent To Leave \& Turnover For Hospital-Based Nurses: A Review Of The Research Literature. International Journal of Nursing Studies, No. 44, p. 297 314.

Cropanzano, R., \& Greenberg, J., 1997. Progress In Organizational Justice : Tunneling Through The Maze. International Review Of Industrial \& Organizational Psychology. New York : John Wiley \& Sons.

Cropanzano, R., Byrne, Z.S., Bobocel, D.R., \& Rupp, D.E., 2001. Moral Virtues, Fairness Heuristics, Social Entities, \& Other Denizens of Organizational Justice.Journal Of Vocational BehaviorVol. 58, 2001, p. 164 - 209.

Cropanzano, R., Bowen, D.E., \& Gilliland, S.W., 2007. The Management Of Organizational Justice. Academy Of Management Perspectives.

Dailey, R.C. \& Kirk, D.J., 1992. Distributive \& Procedural Justice As Antecedents Of Job Dissatisfaction \& Intent To Turnover. Human Relations, Vol. 45, No. 3, p. $305-317$.

De Gieter, S., Hofmans, J., \& Pepermans, R., 2011.Revisiting The Impact Of Job Satisfaction \& Organizational Commitment On Nurse Turnover Intention: An Individual Differences Analysis. International Journal of Nursing Studies, No. 48, p. 1562-1569.

Dundar, T. \& Tabancali, E., 2012.The Relationship Between Organizational Justice Perceptions \& Job Satisfaction Levels. Procedia - Social and Behavioral Sciences, No.46, p. $5777-5781$.

Elamin, A.M., \& Alomaim, N., 2011. Does Organizational Justice Influence Job Satisfaction And Self-Perceived Performance In Saudi Arabia Work Environment ? International Management Review, Vol. 7, No.1, p. 38-49.

Greenberg, J., 1987. A Taxonomy Of Organizational Justice Theories. Academy Of Management Review, Vol. 12, No. 1, p. 9-22.

Greenberg, J., 1990. Organizational Justice: Yesterday, Today, And Tommorow. Journal Of Management, Vol. 16, No. 2, p. $399-432$. 
Ho, W-H, Chang, C. S., Shih, Y-L., \& Liang, R-D, 2009. Effects Of Job Rotation \& Role Stress Among Nurses On Job Satisfaction \& Organizational Commitment. BMC Health Services Research 2009, No. 9, p. 1 - 10.

Humborstad, S.I.W., \& Perry, C., 2011. Employee Empowerment, Job Satisfaction, And Organizational Commitment: An In-Depth Empirical Investigation. Chinese Management Studies, Vol. 5, No. 3, p. $325-344$.

Kim, W. G., Leong, J. K., Lee, Y-K., 2005. Effect Of Service Orientation On Job Satisfaction, Organizational Commitment, \& Intention Of Leaving In A Casual Dining Chain Restaurant. Hospitality Management No. 24, p. 171-193.

Koh, Hian Chye dan El'fred H.Y. Boo. 2004. Organizational Ethics and Employee Satisfaction and Commitment. Management Decision, Vol.42, No.4, pg 677-693.

Kim, W.G. \& Brymer, R. A., 2011. The Effects Of Ethical Leadership On Manager Job Satisfaction, Commitment, Behavioral outcomes, \& Firm Performance. International Journal of Hospitality Management No. 30, p. 1020- 1026.

Maier, C., Laumer, S., Eckhardt, A., \& Weitzel, T., 2012. Analyzing The Impact Of HRIS Implementations On HR Personnel's Job Satisfaction \& Turnover Intention. Journal of Strategic Information Systems, No. XXX, p. $1-15$.

Masterson, S.S., Lewis,K., Goldman, B.M., \& Taylor, M.S., 2000. Integrating Justice $\&$ Social Exchange : The Differing Effects Of Fair Procedures \& Treatment On Work Relationships. Academy Of Management Journal, Vol. 43, No. 4, p. 738 748 .

McAuliffe, E., Manafa, O., Maseko, F., Bowie, C., \& White, E., 2009. Understanding Job Satisfaction AmongstMid-Level Cadres In Malawi: The Contribution Of Organisational Justice. Reproductive Health Matters, Vol. 17, No. 33, p. 80 - 90.

McFarlin, D.B. \& Sweeney, P.D., 1992.Distributive \& Procedural Justice As Predictors Of Satisfaction With Personal \& Organizational Outcomes. Academy Of Management Journal, Vol. 35, No. 3, p. 626-637.

Memarzadeh, G. \& Mahmoudi, R.K., 2010. Applying Organizational Concepts In The Iran Public Sector: A Preliminary Empirical Work On Justice. European Journal Of Social Sciences, Vol. 14, No. 4, p. $594-605$.

Meyer, J.P., \& Allen, N.J., 1991. A Three - Component Conceptualization Of Organizational Commitment. Human Resource Management Review, Vol. 1, No. 1, p. $61-89$.

Meyer, J.P., Allen, N.J., \& Smith, C.A., 1993. Commitment \&Occupations : Extension \& Test Of A Three-Components Conceptualization. Journal of Applied Psychology, Vol. 78, No. 4, p. $538-552$. 
Meyer, J.P., Stanley, D.J., Herscovitch, L., \& Topolnytsky, L., 2002. Affective, Continuance, \& Normative Commitment To The Organization : A Meta-analysis Of Antecedents, Correlates, \& Consequences. Journal Of Vocational Behavior No. 61, p. 20-52.

Nadiri, H. \& Tanova, C., 2010. An Investigation Of The Role Of Justice In Turnover Intentions, Job satisfaction, \& Organizational Citizenship Behavior In Hospitality Industry. International Journal of Hospitality Management, No. 29, p. $33-41$.

Nagar, K., 2012. Organizational Commitment \& Job Satisfaction Among Teachers During Times Of Burnout. The Journal for Decision Makers, Vol. 37, No. 2, p. 43 $-60$.

Noe, R.A., Hollenbeck, J.R., Gerhart, B., \& Wright, P.M., 2011. Manajemen Sumber Daya Manusia: Mencapai Keunggulan Bersaing, Edisi 6. Penerbit Salemba Empat.

Odom, R.Y., Boxx, W.R., \& Dunn, M.G., 1990. Organizational Cultures, Commitment, Satisfaction, \& Cohesion. Public Productivity \& Management Review, Vol. 14, No. 2, p. 157 - 169.

Robbins, S.P., \& Judge, T.A., (2008). Perilaku Organisasi, Edisi 2. Penerbit Salemba Empat.

Samad, 2006. Predicting organizational justice: The case of Malaysian Government Doctors, The Juornal of American Academy of Business Cambridge. Vol.8 No. 2 Maret.

Samad, Sarminah, 2006, "Procedural and Distributif Justice: Differential Effects on Employees' Work Outcomes", The Business Review, Cambridge, Summer, 5 (2), 212-218.

Simamora, Henry. 2004. Manajemen Sumber Daya Manusia, Edisi Ketiga. Yogyakarta: Bagian Penerbitan Sekolah Tinggi Ilmu Ekonomi YKPN.

Sugiarti, T., 2005, Reaksi Pekerja Terhadap Downsizing: Anteseden dan Konsekuensi dari Keadilan Prosedural, Interpersonal dan Informasional. Makalah Simposium Nasional Mahasiswa dan Alumni PascaSarjana Ilmu Ekonomi, dalam acara Dies Natalis 25 Program Magister Sains Dan Doktor Ilmu Ekonomi Universitas Gadjah Mada Yogyakarta.

Tjahjono, Heru, 2007, Keadilan Distributif dan Keadilan Prosedural Dinilai Adil Bagi Sebagian Karyawan, Universitas Gadjah Mada, 2010 diakses dari http://www.ugm.ac.id/index.php?page=rilis\&artikel=1671 pada tanggal 22 Maret 2010.

Thibaut, J. \& Walker, L., 1978. A Theory Of Procedure. California Law Review, Vol. 66, Issue 3, p. 541 - 566. 
Lino Da Silva Saldanha, Wy. Gd. Supartha, Gd. Riana., Pengaruh Keadilan Organisasional........

Whisenant, W., \& Smucker, S., 2006. Organizational Justice And Job Satisfaction : Perceptions Among Coaches Of Girls' Teams. Journal Of Research, Vol. 2, Issue 2, p. $47-53$.

Yang, J-T., 2010. Antecedents \& Consequences Of Job Satisfaction In The Hotel Industry. International Journal Of Hospitality Management, No., p. 29 609-619.

Yang, M-L, 2012.Transformational Leadership \& Taiwanese Public Relations Practitioners' Job Satisfaction \& Organizational Commitment.Social Behavior \& Personality, Vol. 40, No. 1, p. $31-46$.

Zainalipour, H., Fini, A.A.S., \& Mirkamali, S. M., 2010. A Study Of Relationship Between Organizational Justice \& Job Satisfaction Among Teachers In Bandar Abbas Middle School. Procedia - Social and Behavioral Sciences, 